\title{
„Slovník“" aneb Vídeňský učitel v roli pašeráka exilové literatury ${ }^{1}$
}

\author{
JiTKa HaNÁKOVÁ
}

\begin{abstract}
The "Dictionary" or a Viennese teacher in the role of smuggler of exile literature
The arrival of the occupying armies in August 1968 and the subsequent normalisation purges resulted in an unusually large wave of emigration. The regime responded to this by closing state borders in October 1969. The great number of refugees brought new stimuli to activities in exile, such as establishment of new exile periodicals and publishing houses, which contributed to preserving independent Czech literature.

Some of the books produced by publishing houses in exile were always intended for readers in Czechoslovakia, where they were transported using various smuggling routes. A new smuggling channel was created in 1983 - the so-called Austrian route - by agreement between Jiří Pelikán and Vilém Prečan. They used the code word "dictionary" for this route when communicating with each other. The "dictionary" was a large passenger car, which Jiří Pelikán authorised Adolf Müller to purchase and which was modified by experts from the American secret service who created a secret compartment for transporting books and periodicals in the luggage space. Vilém Prečan and Josef Jelínek then came up with a way to fill the compartment. Young teacher Helmut Bachmann, took receipt of the car from V. Prečan in Vienna. He was talked into collaborating by Jana Stárková. Bachmann drove the car to Czechoslovakia as a tourist roughly once every three months and Jiřina Šiklová organised receipt of the consignments in Prague. The compartment was created so cleverly that the Czechoslovak border control forces were unable to find it, even after thoroughly inspecting the car for forty minutes, something that occurred in March 1984. This transport channel, financed by Jiří Pelikán, was used from the summer of 1983 until the end of 1987 , when the car was taken out of operation.
\end{abstract}

KEY wORDs: Czechoslovak exile - smuggling of literature - opposition - Jiří Pelikán - Vilém Prečan - Helmut Bachmann - Jana Stárková - Jiřina Šiklová - Adolf Müller - Josef Jelínek

ConTACTs: Mgr. Jitka Hanáková, Archiv Národního muzea - Československé dokumentační středisko, Na Zátorách 6, 17000 Praha 7; e-mail: jitka.hanakova@nm.cz

Demokratizační reformy, které se začaly uskutečňovat zejména od jara 1968, byly po srpnové okupaci Československa vojsky pěti armád Varšavské smlouvy postupně rušeny. Brzy byla opět zavedena tvrdá cenzura, jejíž zrušení patřilo k nejvýraznějším reformním krokům „pražského jara“. Důsledkem těchto událostí a následných normalizačních čistek byla mimořádně silná vlna emigrace, kterou zastavilo až uzavření hranic v říjnu 1969. Velké množství uprchlíků přineslo nové podněty do exilové činnosti. Vznikla nová exilová periodika a nakladatelství, která přispívala k zachování nezávislé české a slovenské literatury. Č́st produkce exilových nakladatelství byla vždy určena pro domácí čtenáře v Československu, kam se dostávala různými ,pašovacími“ kanály. Prostřednictvím vytvořených kurýrních cest byly opoziční skupiny v Československu zásobovány nejen knihami a časopisy vydávanými v zahraničí, ale také technickým zařizením pro vydávání samizdatové literatury,

1 Předložená práce vznikla za finanční podpory Ministerstva kultury v rámci institucionálního financování dlouhodobého koncepčního rozvoje výzkumné organizace Národní muzeum (DKRVO 2019-2023/16.III.b, 00023272) 
jako byly kopírky, psací stroje a později i počítače. První posrpnový dopravní a komunikační kanál vytvořil Jan Kavan se skupinou svých přátel v Londýně již v roce 1970. Na české straně se do této činnosti zapojil Jiří Müller, než byl v roce 1971 uvězněn, a po něm Petr Pithart. Během roku 1971 se do systému předávání zásilek zapojila Jiřina Šiklová a o tři roky později Vilém Prečan, který se na této aktivitě podílel do doby, než v roce 1976 odešel do exilu, kde sehrál významnou úlohu při pašování literatury a technické pomoci čs. opozici. ${ }^{2}$ Tajný kanál Jana Kavana nebyl jediným spojením přes železnou oponu, ale byl hlavním a nejdéle fungujícím a také přepravil největší objem zakázané literatury oběma směry. Spojení domácí opozice s exilem pomáhali udržovat rovněž diplomaté západních ambasád. Zvláště po vzniku Charty 77 se zvýšila potřeba spolehlivých komunikačních spojení na Západ.

Státní bezpečnost se neustále snažila kurýrní cesty sledovat a odhalovat. V dubnu 1981 zadržela na hraničním přechodu v Dolním Dvořišti karavan vypravený z Londýna Janem Kavanem. ${ }^{3}$ Ve voze, jímž cestovali mladí Francouzi právník Gilles Thonon a studentka práv Francoise Anisová, byly zakázané exilové knihy a periodika, ale i štítky s adresami českých odběratelů exilového časopisu Svědectví. Brzy nato zahájila Státní bezpečnost rozsáhlou policejní akci, při níž bylo v Praze, Brně a Bratislavě zadrženo kolem třiceti osob. Proti dvanácti ze zadržených bylo zahájeno trestní stíhání pro podvracení republiky, později známé jako proces „Jiřina Šiklová a spol.“4 Tím byla výrazně narušena léta budovaná spojení pro předávání informací, knih a dokumentů z Československa. Musely se hledat nové bezpečné cesty. Spojení mezi domácí opozicí a exilem pomáhali udržovat také diplomaté západních ambasád, zejména německé, ale i rakouské a švédské, a to zejména po roce 1981. Jiřina Šiklová byla již od roku 1977 ve spojení s Peterem Tejlerem, kulturním atašé švédské ambasády, s jehož pomocí udržovala korespondenční spojení s exilem. ${ }^{5}$ Po zadržení kamionu se podařilo Bedřichu Loewensteinovi ${ }^{6}$ vytvořit novou cestu přes západoněmecké velvyslanectví. Ale i tudy mohla procházet jen korespondence. Největší zásluhy na tom, že rukopisy zakázaných autorů se dostaly na Západ a zpět do Československa jejich tištěné verze, měl západoněmecký kulturní atašé Wolfgang Scheur. Na jeho působení navázal kanadský

2 Srov. Jiřina ŠIKLOvÁ, Zpráva o části opozičního hnutí v letech 1971-1981 v Praze; in: Ročenka Československého dokumentačního střediska 2004-2007, Praha, 2008, s. 285-295.

3 Státní bezpečnost odhalila kamion díky informacím svých dvou agentů. V Praze se Pavlu Muraškovi podařilo zapojit do distribučního systému pašované literatury a ve Vídni spravoval sklad exilových tiskovin dlouholetý agent československé rozvědky Ivo Šafár. Srov. Radek ScHováneK, Zakázané knihy pro Čechy skutečně platila CIA, Echo24.cz, https:/echo24.cz/a/itP5G/zakazane-knihy-pro-cechy-skutecne-platila-cia. Byl to poslední kamion, který Státní bezpečnost odhalila, ale nebyl první. V červenci 1978 byl zadržen mikrobus, jímž pašoval exilovou literaturu do Československa Adolf Müller. Posádku, kterou tvořil studentský pár Gerhard Küchen a Ulrika Ackermannová, po měsíci věznění propustili. Viz Adolf MüLlER, Byly i jiné mikrobusy..., Listy, č. 1, 1993, s. 67-69.

4 Viz Jitka Hanáková, Tisková služba Ivana Medka, služba domovu; in: Jitka Hanáková (ed.), Sborník Národního muzea v Praze, řada A-Historie, 2016, roč. 70, č. 1-2, s. 32.

5 Tato cesta byla známá pod krycím názvem Vasco da Gama.

6 Bedřich Loewenstein (29. 6. 1929 - 11. 5. 2017) byl významný česko-německý historik. V letech 1970-1978 pracoval jako tlumočník a překladatel na západoněmeckém velvyslanectví v Praze. Díky svým kontaktům zprostředkoval spojení mezi domácí opozicí a exilem. Napomáhal tak komunikaci mezi disentem a jejich zahraničními partnery. V lednu 1979 odcestoval do Západního Berlína, kde působil jako profesor historie v Ústavu Friedricha Meineckeho. Po listopadu 1989 přednášel na UK a publikoval v domácích odborných periodikách a sbornících. 


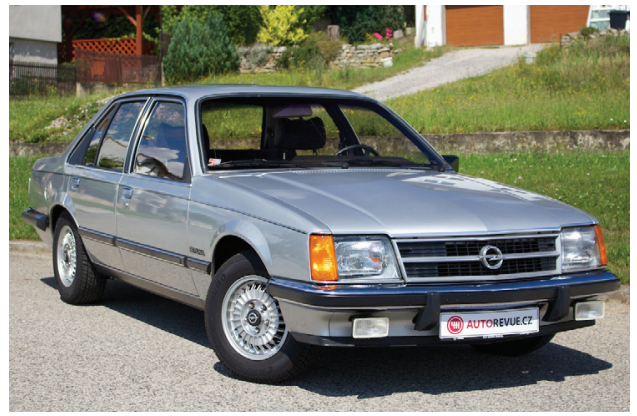

Obrázek 1 - Takto vypadalo auto Opel Commodore, kterým se pašovala literatura do Československa. Ve skutečnosti však mělo auto zlatohnědou barvu. (Obrázek převzat z www.autorevue.cz) diplomat Peter Bakewell a po něm německý diplomat Peter Metzger.7 Kromě těchto diplomatických spojení se mnozí exulanti soustředili na vytváŕení vlastních kurýrních cest. Počátkem roku 1983 přišel Jiří Pelikán ${ }^{8} \mathrm{~s}$ nápadem na pašování literatury do Československa pomocí upraveného osobního vozu. Chtěl tím odlehčit přeplněný sklad exilové literatury, který měl ve svém hannoverském bytě Vilém Prečan. ${ }^{9}$ Současně s tím plánoval omezit část kurýrních cest, jež zajištoval Alexandr Tomský, zakladatel exilového nakladatelství Rozmluvy. Ten posílal domů pětikilové zásilky, které byly vzhledem $\mathrm{k}$ danému objemu př́liš drahé. Kurýry těchto zásilek, jako i mnoha dalších, platil právě Jiřri Pelikán. ${ }^{10}$ Od dubna tak začali Jiř́ Pelikán a Vilém Prečan plánovat možnosti nového pašovacího kanálu. Ve vzájemné komunikaci používali pro tuto cestu krycí název „Slovník“. Tento pašovací kanál byl také označován jako tzv. rakouská cesta. Především hledali vyhovující starší auto, které by se dalo pro tento účel patřičně uzpůsobit. $\mathrm{V}$ úvahu přicházelo i upravené vozidlo, které dříve používal $\mathrm{k}$ převozu Svědectví a dalších tiskovin Pavel Tigrid. Ale vzhledem k tomu, že auto bylo zakoupeno na podzim 1980 již ojeté a bylo značně opotřebované, od této možnosti ustoupili. ${ }^{11}$ Shodli se na tom, že auto pro tyto účely zakoupí v Rakousku, odkud se bude exilová literatura pašovat do Československa, a k potřebným úpravám ho převezou do Německa. Na zakoupení vhodného vozu se Jiří Pelikán domluvil s Adolfem Müllerem ${ }^{12}$, zakladatelem nakladatel-

7 Srov. Jitka Hanáková (ed.), Archiv svobody na zámku Schwarzenbergu, s. 131.

8 Jiř́ Pelikán (7. 2. 1923 - 26. 6. 1999) byl novinář, publicista a politik. Patřil k předním představitelům komunistického studentského hnutí. V padesátých letech byl předsedou Mezinárodního svazu studenstva. V šedesátých letech byl mj. ředitelem čs. televize. Během pražského jara se aktivně podílel na demokratizačním procesu v Československu. Později byl odeslán do diplomatických služeb. V září 1969 požádal v Itálii o politický azyl. Od roku 1971 vydával v Ř́mě časopis Listy. V letech 1979-1989 byl poslancem Evropského parlamentu za Italskou socialistickou stranu. Výrazně se zapojil do exilové činnosti, patřil např. mezi zakladatele ČSDS v Scheinfeldu. Významně pomáhal také domácí opozici, měl své pašovací kanály, kterými do Prahy posílal časopisy a různé materiály. Po roce 1989 přenesl vydávání Listů do Prahy.

9 Vilém Prečan je český historik, který se zabývá moderními českými dějinami. Po studiích působil dva roky v Bratislavě a v roce 1957 nastoupil do Historického ústavu ČSAV v Praze. Po srpnové okupaci Československa se podílel na vydání publikace Sedm pražských dnů, 21.-27. 8. 1968, tzv. Černé knihy. Za tuto dokumentaci prvního týdne okupace byl propuštěn ze zaměstnání, vyloučen z KSČ a trestně stíhán. Pracoval jako topič, uklízeč, vrátný a šatnář. V červenci 1976 se vystěhoval do SRN, kde se aktivně zapojil do exilové činnosti. Sehrál významnou úlohu při pašování literatury a technické pomoci čs. disentu. V roce 1986 stál u zrodu exilového Československého dokumentačního střediska nezávislé literatury. Po návratu do Československa založil Ústav soudobých dějin ČSAV.

10 Rozhovor autorky s Vilémem Prečanem, 18. 2. 2020.

11 Dopis Viléma Prečana Jiřímu Pelikánovi z 10. března 1983, osobní archiv Viléma Prečana.

12 Adolf Müller (1. 12. 1929 - 26. 3. 2002) byl český politolog, publicista a nakladatel. Patřil mezi reformní komunisty. V roce 1968 odešel do exilu. Usadil se v západním Německu, kde přednášel politologii na německých univerzitách. V roce 1971 založil v Kolíně nad Rýnem spolu s Bedřichem Utitzem exilové nakladatelství Index. Účasnil se také distribuce časopisu Listy a vydávání časopisu 150000 slov v redakci 


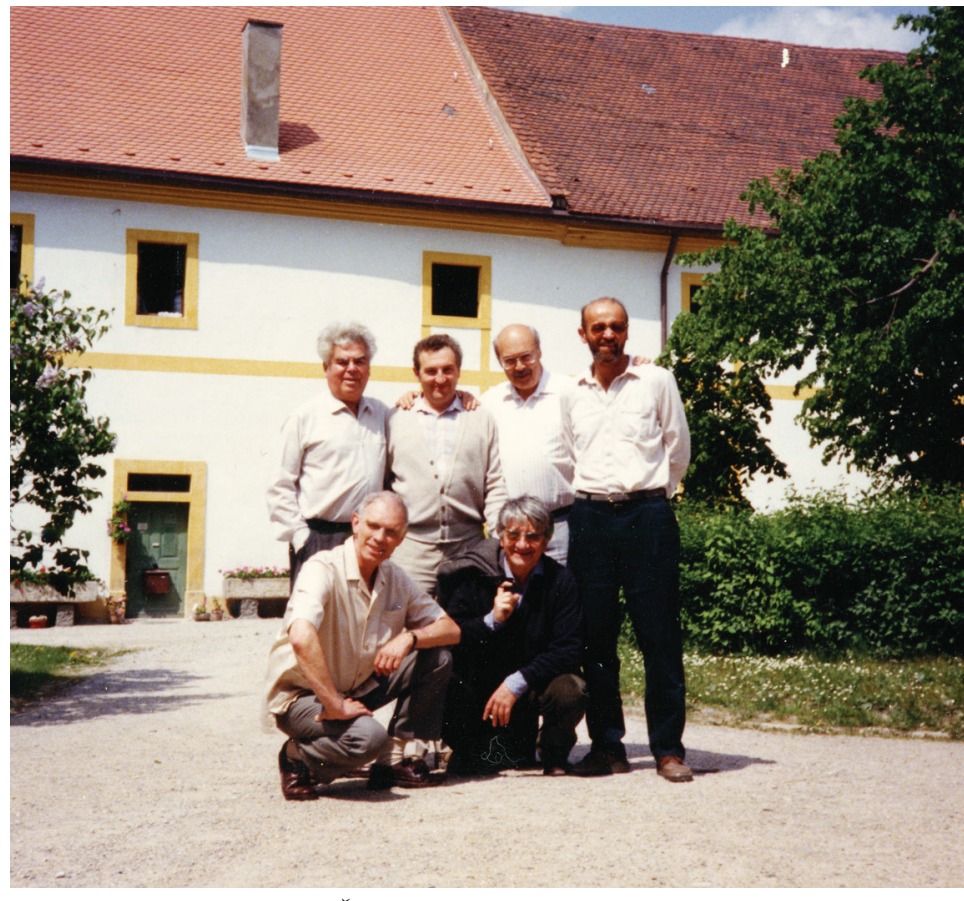

Obrázek 2 - Před sídlem ČSDS na zámku Schwarzenbergu; nahoře zleva:

J. Pelikán, V. Prečan, J. Jelinek, kteři se podíleli na ,Slovniku“, dále I.

Kunstýŕ; dole zleva: I. Medek, J. Vladislav, ANM - ČSDS. ství Index, který měl s pašováním literatury upravenými vozy zkušenosti již od sedmdesátých let. $^{13}$ Adolf Müller dovezl vůz do Frankfurtu nad Mohanem, kde ho pro Jiřího Pelikána upravili odborníci americké tajné služby CIA. V zavazadlovém prostoru vytvořili tajnou schránku - dvojité dno pod podlahou kufru, s malým otvorem vzadu vpravo. Tento důmyslný úkryt měl na výšku asi $12 \mathrm{~cm}$ a pojal až dvanáct kilogramů knih a časopisů.

Takto upravený zlatohnědý Opel Commodor si Vilém a Helena Prečanovi vyzvedli 25. července 1983 na sjednaném místě ve Frankfurtu, kam brzy ráno dorazili z Hannoveru. Přesné instrukce o klíčích a místě parkování dostal Vilém Prečan od Jiřího Pelikána, jelikož Američané, kteří auto upravovali, chtěli zůstat v utajení. ${ }^{14}$

Z Frankfurtu manželé Prečanovi pokračovali přímo do bavorského Scheinfeldu, na hrad Schwarzenberg, kde je čekalo vůbec první setkání s knížetem Karlem Schwarzenbergem. Setkání to bylo první, ale ne poslední, v roce 1986 poskytl Karel Schwarzenberg na svém zámku prostory pro právě vzniklé Československé dokumentační středisko nezávislé literatury (ČSDS), které vedl Vilém Prečan. Nezapomenutelnou první cestu do Scheinfeldu jim v parném létě připravila nefungující klimatizace, zjevný následek proběhlých úprav. ${ }^{15}$

Antonína J. Liehma. Od sedmdesátých let se podílel na pašování knih a periodik do Československa. Po roce 1989 přednášel stř́idavě v Německu a České republice.

13 Nakladatelství Index již v roce 1974 zakoupilo starý VW - mikrobus, který zaplatil Pavel Tigrid a k pašování ho upravil mechanik František Dražný z Hessenska. V zabudovaných schránkách vezl najednou několik set knih a časopisů. Do Čech jezdil pravidelně třikrát až čtyřikrát do roka, než byl v roce 1978 odhalen. Viz Adolf Müller, Byly i jiné mikrobusy..., Listy, č. 1, 1993, s. 67-69. Srov. Petr OrsáG, S komunisty se mluví (ba i spolupracuje). Pavel Tigrid a reformní komunisté v exilu po srpnu 1968, in: Jitka Hanáková a kol., Pavel Tigrid. Svédek dvacátého století, Praha, 2018, s. 28-29.

14 Rozhovor autorky s Vilémem Prečanem, 18. 2. 2020.

15 Rozhovor autorky s Helenou Prečanovou, 18. 2. 2020. 
Pozdě večer téhož dne se Prečanovi přesunuli do blízkého Erlangenu ke svému prríteli a spolupracovníkovi Josefu Jelínkovi. ${ }^{16}$ Zde se měla připravit první tajná zásilka určená do Prahy. Vilém Prečan svého př́itele dopředu informoval o svém př́ijezdu dopisem ze dne 17. července 1983: „,...To všechno bych chtěl napakovat během úterka 26. července, ale pozor: Nemohu to dělat nikde před domem, $v$ Tvém okoli. Bud' bych odjel s autem do lesa, kde bychom byli sami, beze svědků, anebo - kdyby nedej bože pršelo - potřebovali bychom nějaký přistřešek. Ale opět, beze svědků, abychom nebyli nápadní. Všechno pochopíš, až uvidíš... "17 Spolu s Josefem Jelínkem a jeho synem, mladým lékařem, pak během následujícího dne vymysleli způsob, jak těžko přístupný prostor naplnit. Připravili si půdorys schránky a vytvořili důmyslný systém, kdy pomocí igeli-

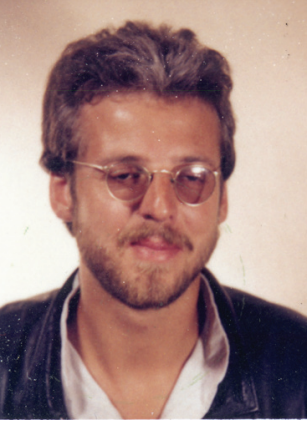

Obrázek 3 - Helmut Bachman v osmdesátých letech, $A N M-\check{C} S D S$. tových sáčků a široké lepicí pásky vše zabalili tak, že vlastní naložení a vyložení zásilky trvalo pouhé dvě až tři minuty.

Odtud pokračovali Prečanovi do Vídně, která byla vybrána za výchozí místo pašování směr Praha zejména pro svou strategickou polohu blízko hranic s Československem.

Důležitý úkol - najít vhodného kurýra - dostala na starost Jana Stárková18 ${ }^{18}$ dcera Jiřího Stárka, dobrého prŕítele Jiř́ho Pelikána. Vilém Prečan ji na doporučení J. Pelikána oslovil, zda by nenašla vhodnou osobu, která by byla z Rakouska, nejlépe z Vídně, a byla by ochotna pomáhat pašovat materiály do Československa. ${ }^{19}$ Počátkem června se tedy Vilém Prečan sešel ve Vídni s Janou Stárkovou a na všem potřebném se domluvili. Mladá Jana Stárková udělala na V. Prečana velmi dobrý dojem, jak se on sám zmiňuje v dopise J. Pelikánovi „,... je výborná, efektivní a spolehlivá... "20.

Jana Stárková se při hledání vhodného kurýra obrátila na rakouské prrátele, kteří se velmi zajímali o vývoj v Československu. Mnozí byli levicově orientovaní, zejména skupina revolučních marxisti̊, a jak Jana Stárková vzpomíná „, ...někdo z nich mně doporučil prá-

16 Josef Jelínek (8. 10. 1927 - 21. 4. 2015) byl skaut, politický vězeň, publicista a vydavatel. V patnácti letech se zapojil do protinacistického odboje a za tuto činnost obdržel v roce 1946 medaili od E. Beneše. Po únorovém převratu byl aktivní v protikomunistickém odboji. V červenci 1948 byl zatčen a odsouzen na šest let. Po propuštění v roce 1953 střídal zaměstnání a v ř́íjnu 1968 emigroval. Usadil se v německém městě Erlangen. Velmi aktivně se angažoval v činnosti čs. exilu. Od roku 1980 spolupracoval s V. Prečanem, vytvářel kopie samizdatových knih a časopisů pro západní knihovny a pomáhal připravovat zásilky knih pro domov. Pro nedostatečnou přepravní kapacitu začal vyrábět zmenšené kopie exilových knih, tzv. Kolibřiky. Nevýhody hưř̀e čitelného tisku vyvážilo důmyslné umístění zvětšovací lupy do hřbetů knížek. V roce 1986 se stal jedním ze zakládajících členů ČSDS.

17 Dopis Viléma Prečana Josefu Jelínkovi, 17. 7. 1983. Již od června se na Jelínkovu adresu posílaly materiály určené k pašování tímto autem.

18 Jana Stárková je česko-rakouská historička, překladatelka a publicistka, autorka studií o československém exilu. Velmi aktivně se zapojila do činnosti vídeňského exilu. Organizovala a účastnila se veřejných demonstrací na podporu čs. opozice a vězněných obhájců lidských práv. Podílela se na pašování exilové literatury do Československa a Mad'arska. V roce 1982 stála u zrodu Mezinárodní helsinské federace pro lidská práva ve Vídni. Po roce 1989 přednáší střídavě na univerzitách v Čechách a ve Vídni. Působí ve Vídeňském Wiesenthalově ústavu pro výzkum holokaustu.

19 Rozhovor autorky s Janou Stárkovou, Vídeň 16. 5. 2017.

20 Dopis Viléma Prečana Jiřímu Pelikánovi, 10. 8. 1983. 


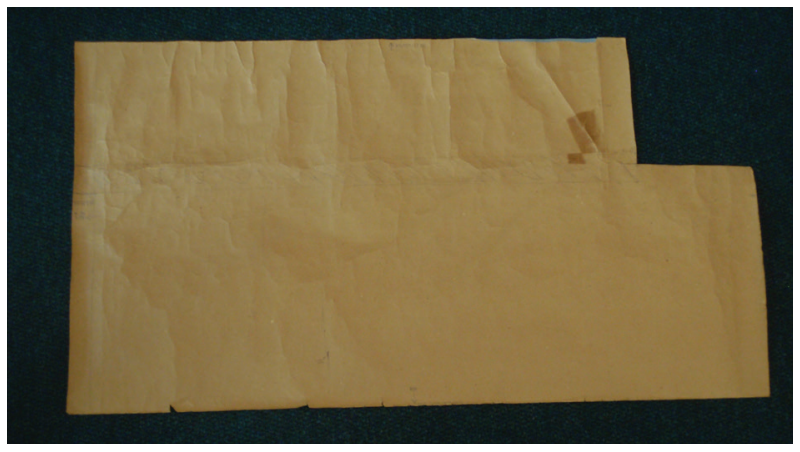

Obrázek 4 - Půdorys tajné schránky zavazadlového prostoru osobního auta, které sloužilo pro převoz zakázané literatury, $A N M-\check{C} S D S$.

vě Helmuta Bachmanna ${ }^{21}$, kterého jsem vỉbec neznala, a po jednom, dvou rozhovorech se mi zdál ideální (...) já jsem mu upřesnila, o co se jedná, přesto, že já jsem houby věděla přesné údaje, a on řekl ano... ".22 Helmut Bachmann se v době studií angažoval $\mathrm{v}$ politické skupině, která byla orientována na Trockého permanentní revoluci. K tomu dodává: „, Také jsme podporovali politickou opozici v zemích východní Evropy a vydávali jsme politický časopis Gegenstimmen. Podle našeho názoru reprezentoval politický systém ve východní Evropě typ degenerovaného socialismu. Takže jsme cítili s opozicí solidaritu. Když jsem začal se svými cestami do Prahy, již jsem členem této skupiny nebyl, ale moji prátelé, kteři měli stále kontakty s disidenty, mě požádali, abych tuto práci vykonal (...). Přímo mě kontaktovala má dobrá prritelkyně z této trockistické skupiny, která pracovala v redakci tohoto časopisu “. ${ }^{23}$ Stárková se s Bachmannem několikrát sešla, řekla mu, oč se zhruba jedná, že bude mít zaplacený hotel a osobní výdaje, ale veškeré další informace získá od Viléma Prečana, jakmile přijede do Vídně.

První setkání Viléma Prečana a Helmuta Bachmanna se uskutečnilo v pátek 29. července 1983 v jedné vídeňské kavárně. Ještě téhož dne mu V. Prečan předal auto a on stejný večer odjel tímto vozem na svou první kurýrní cestu ${ }^{24}$ do Prahy. Po návratu do Vídně v neděli 31. července ${ }^{25}$ probral s V. Prečanem své první zkušenosti z úspěšné cesty a dohodli následující jízdu hned na srpen. Nevynechali ani finanční stránku projektu. Vypočítali, že výlohy na jednu cestu se budou pohybovat kolem 500 až 600 západoněmeckých marek. Bude záležet na tom, zda pojede Bachmann sám, či s přítelkyní. První cesta byla méně nákladná, jel sám, a navíc první noc strávil v autě, protože přijel pozdě a neměl zajištěn nocleh. Hned na místě si Bachmann se svým protějškem dohodl následující čas a místo předání zásilky, a tím

21 Helmut Bachmann je středoškolský učitel. Vystudoval politologii a pedagogiku, doktorát má z politologie a filozofie. V letech 1977-1985 učil na středních školách ve Vídni, poté pracoval v městské radě ve Vídni jako referent pro rozvoj školství. Od roku 1988 byl zaměstnancem Ministerstva školství, kde pracoval na různých pozicích až do odchodu do důchodu v roce 2015. Jako student působil v politické skupině, která byla orientovaná na permanentní revoluci, ale také podporovala politickou opozici v zemích východní Evropy.

22 Rozhovor autorky s Janou Stárkovou, Vídeň 16. 5. 2017.

23 Rozhovor autorky s Helmutem Bachmannem, Vídeň 17. 5. 2017.

24 Byla to jeho první cesta nově vytvořeného kanálu, ale již v květnu 1982 podnikl svou první kurýrní jízdu speciálně upraveným starším vozem značky Volkswagen. Nebyla to ale úspěšná operace, protože osoba, jíž měl doručit zásilku, nedorazila. Neměl na ni kontakt, ale na domluvené místo přišel šest či sedmkrát. Protože se mu nepodařilo vtěsnat matriály zpět do prostoru skrýše uvnitř dveří, musel je cestou vyhodit v lese. Po návratu do Vídně se dozvěděl, že daná osoba onemocněla. Rozhovor autorky s Helmutem Bachmannem, 17. 5. 2017.

25 Archiv Národního muzea - sbírka Československé dokumentační středisko (dále jen ANM - ČSDS), údaje z pasu Helmuta Bachmanna. 


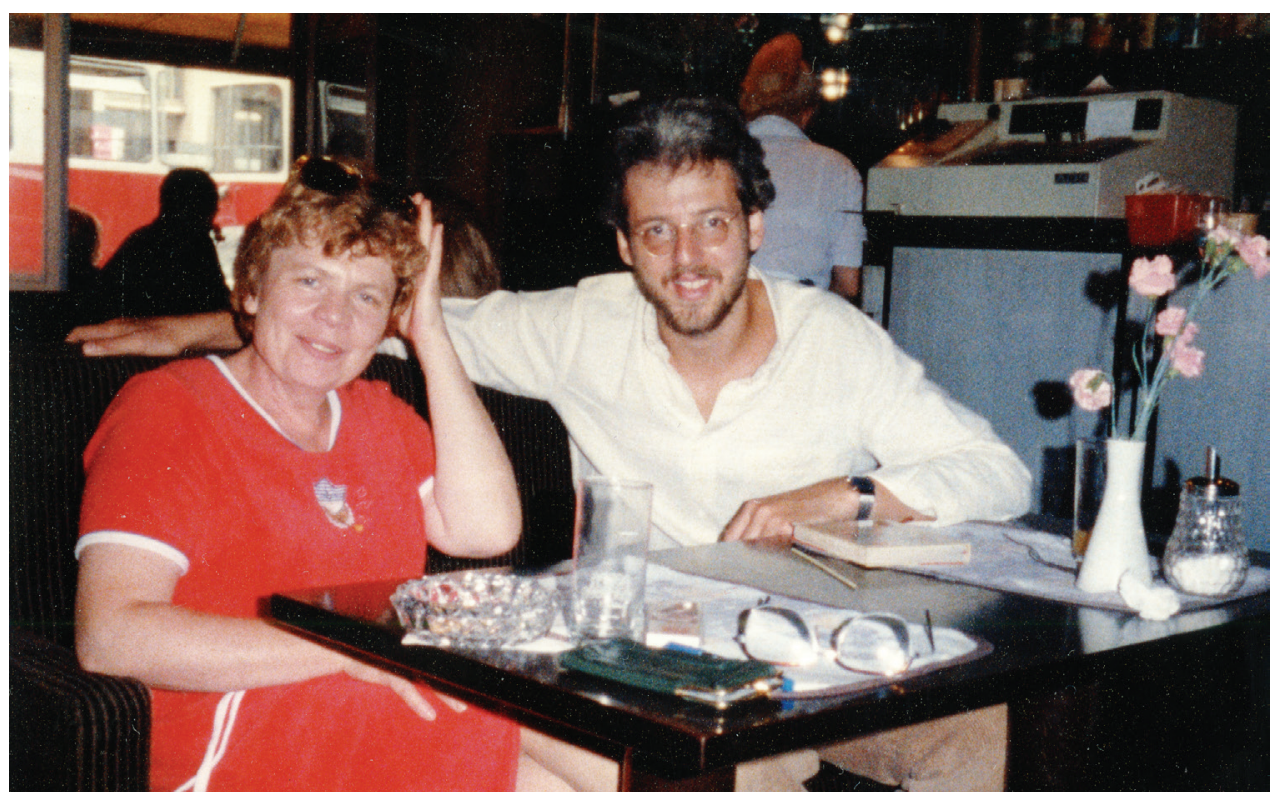

Obrázek 5 - Helena Prečanová s Helmutem Bachmannem ve Vidni 29. července 1983, ANM-ČSDS.

odpadlo riskantní telefonování do Prahy. Vilém Prečan byl s Bachmannem velmi spokojen, jak vyplývá z jeho zprávy Jiřímu Pelikánovi: „Je to mladší člověk (necelých třicet), udělal na mè ten nejlepši dojem, je klidný, vyrovnaný, pohotový a iniciativní, všechno optimální vlastnosti pro tuto práci... "26

V Praze zajišt'ovala agendu tohoto kanálu Jiřina Šiklová, ${ }^{27}$ která organizovala i jiná spojení mezi domovem a politickým exilem. Mimo distribuční kanál Jana Kavana zabezpečovala od konce sedmdesátých let veškerou přepravu samizdatových knih, ineditních materiálů a korespondenci disidentů do zahraničí a současně organizovala př́jem a distribuci exilové literatury, která se dostávala do Československa prostřednictvím Viléma Prečana. Oba měli mezi sebou dohodnutý kódovací systém, s jehož pomocí si sdělovali, kdy přijede kurýr, a dále místo a čas setkání.

Helmut Bachmann se scházel se svým protějškem u Staronové synagogy. První setkání v Praze probíhala s mladým křest’anem s krycím jménem „Bílek“ ${ }^{28}$ Toto krycí jméno bylo zvoleno podle místa setkání u Staronové synagogy, u níž stojí socha Mojžíše od sochaře Fran-

26 Z dopisu Viléma Prečana Jiřímu Pelikánovi, 10. 8. 1983.

27 Jiřina Šiklová je česká socioložka, publicistka, signatářka Charty 77. V šedesátých letech spoluzakládala Katedru sociologie FF UK. Aktivně se podílela na tzv. pražském jaru. V roce 1968 podepsala manifest Dva tisíce slov a rok nato vystoupila z KSČ. V roce 1969 byla mezi prvními, které propustili z Karlovy univerzity. Od počátku sedmdesátých let se podílela na pašování samizdatové a exilové literatury. Za tuto činnost byla v květnu 1981 zatčena a obviněna z podvracení republiky. Všichni obvinění v procesu „Šiklová a spol.“ byli téměř po roce propuštěni, aniž bylo trestní stíhání zastaveno. Po návratu z vězení obnovila pašování literatury a dělala spojku mezi exilem a opozicí až do listopadu 1989. V devadesátých letech založila Katedru sociální práce na FF UK a také Centrum a knihovnu Gender Studies Praha.

28 Vilém Prečan popisoval Jiř́mu Pelikánovi reakci Bachmanna na první setkání s „Bílkem“ takto: „Našeho ,cizince iritovalo, že jeho protějšek je praktikujici křest’an, domorodce zase fakt, že náš ,cizinec'vystoupil z cirkve a je ateista. Bylo z toho dlouhé vysvětlování na obě strany (...). Našeho cizince iritovalo, jak jeho protějšek nekriticky vzhliži k Západu, vůči němuž on sám má poměr kritický. “ Dopis Viléma Prečana Jiřímu 


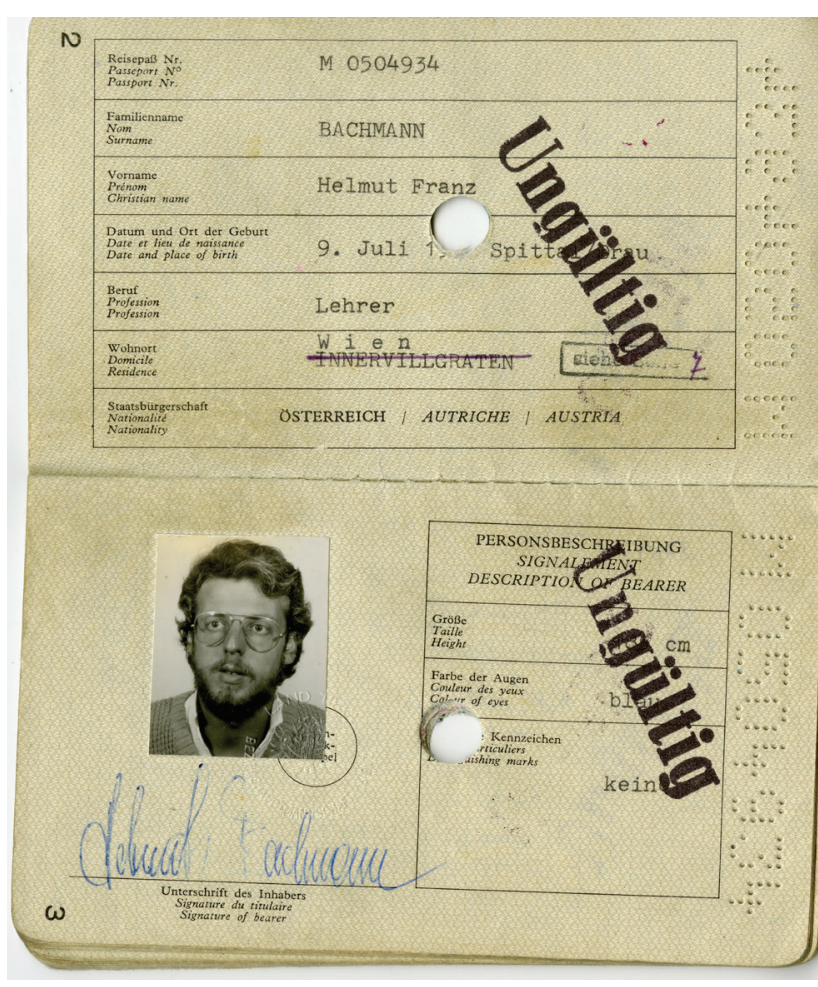

Obrázek 6-Pas Helmuta Bachmanna, který použival při cestách do Prahy, ANM - ČSDS. tiška Bílka. Ono místo setkání se uvádělo kurýrovi z toho důvodu, aby nepřišel k synagoze z druhé strany od Židovského hřbitova nebo Maiselovy ulice. Také se kurýr, který Prahu neznal, mohl snadno na tento pomník zeptat. Místo bylo vybráno i z toho důvodu, že zahraniční turista zde nebyl nápadný, protože téměř každého, kdo v té době přijel do Prahy, zajímaly hodiny na Židovské radnici, jejichž ručičky se otáčejí opačným směrem, a radnice stojí těsně u synagogy. Poznávacím znamením pro domácí spojku byly zahraniční noviny, které kurýr na místě setkání držel v ruce, jelikož v té době zde nebyly úplně dostupné. $\mathrm{Na}$ tomto prvním setkání se teprve kurýrovi sdělilo místo, kde si zásilku od něho druhá strana

převezme. Oněch „Bílkư“ bylo v průběhu let několik, kolem pěti až deseti. Později již Jiřina Šiklová těžko hledala někoho pro roli „Bílka“, a tak se s kurýry setkávala sama. To už si domlouvala sraz mimo jiné na náměstíčku „U Franze Kafky“. Když se tam někdo rozhlížel, šla k němu a zeptala se ho česky, zda má rád Franze Kafku, a když odpověděl česky, odešla. Pokud to byl ten správný ,,posel“", odpověděl, že on má rád... a řekl nějaké jídlo. Potom mu sdělila adresu, kde mají zásilku předat. Pokud se setkání nepovedlo, opakovala se schůzka následujícího dne ve stejný čas na stejném místě. ${ }^{29}$

Helmut Bachmann jel do Československa v roce 1983 celkem třikrát. Druhou cestu podnikl i se svou přítelkyní koncem srpna na již předem domluvenou schůzku. I tentokrát vše proběhlo bez potíží. Na místě si s „Bílkem“ dohodli následující termín na začátek prosince. Tato další akce „slovníkové“ linky opět proběhla k plné spokojenosti všech zainteresovaných. Domluvený termín na konec ledna následujícího roku byl ale posunut. Vilém Prečan dostal z Prahy doporučení, aby tuto linku omezil a provozoval ji řidčeji. Bylo s ní prý př́liš práce

Pelikánovi, 10. 8. 1983. Tento mladý katolík byl pravděpodobně někdo z okruhu kolem Miroslava Tyla, disidenta a signatáře Charty 77, z korespondence autorky s Jiřinou Šiklovou, 23. 11. 2020.

29 Z korespondence autorky s Jiřinou Šiklovou, 23. 11. 2020. Jiřina Šiklová uvádí, že ona také „Bílkem“označovala kurýry, kteří sem přijížděli a setkání měli u synagogy a jejichž jména neznala. Jen jednou se dozvěděla jména kurýrů, těch, kteří byli zadrženi v souvislosti s „kamionem“ - Francouzi Gilles Thonon a Francoise Anisová, jejichž jména se dozvěděla v Ruzyni z vyšetřovacího spisu. Ale to bylo ještě před vznikem tohoto kanálu. 
a zdála se být málo rentabilní. $^{30} \mathrm{~V}$ té době již začala velmi intenzivní spolupráce se západoněmeckým kulturním atašé Wolfgangem Scheurem $^{31}$, který se zařadil do kyvadlové dopravy mezi Jiřinou Šiklovou a Vilémem Prečanem.

Následující cesta mladého páru se uskutečnila 24. bř̀zna 1984, kdy si dvojice prožila na hrani- Obrázek 7 - Obálka, ve které posílal Vilém Prečan Helmutu Bachmannovi cích horké chvilky. literaturu určenou k pašování. V tomtéž obalu se zaslaný materiál i pašoByli podrobeni vel- val, $A N M-\check{C} S D S$.

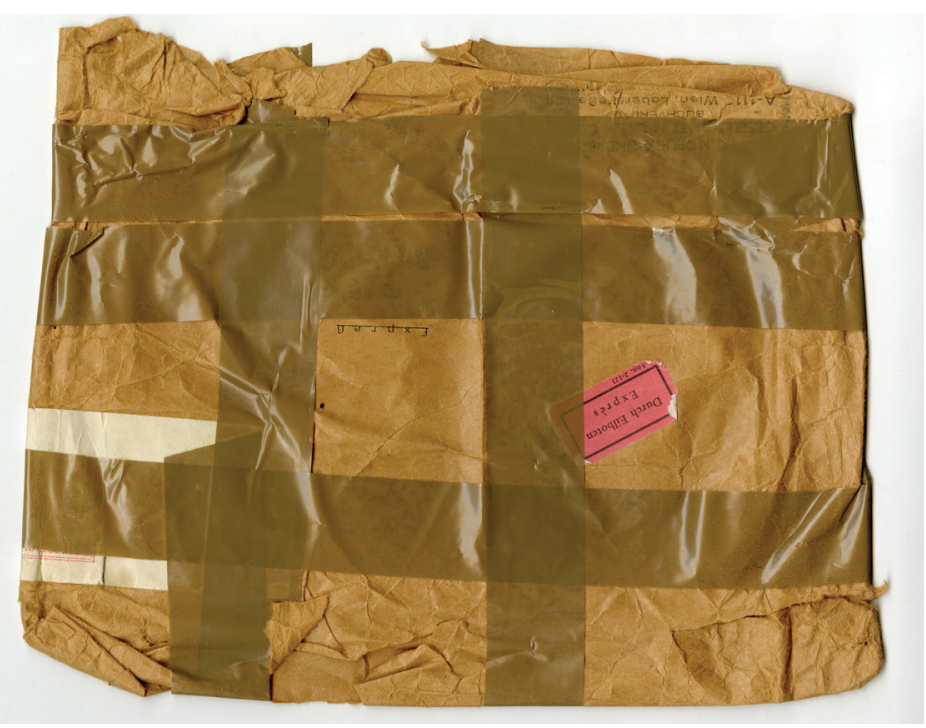

mi důkladné kontrole, která trvala tři čtvrtě hodiny. Celníci prohledali jejich osobní zavazadla a technici zkontrolovali kompletně vůz. Zejména důkladně změřili a proklepali nádrž na benzín. Když zjistili, že tankovali před hranicemi, nastartovali auto a sledovali ukazatel stavu nádrže. Prohledali prostor pod kapotou, kde je motor. Větší pozornost však věnovali zadní části vozu. Ze zavazadlového prostoru auta vyndali rezervní kolo a obě gumové podložky a zkontrolovali všechny sváry. Zrcadlem prohledali podvozek a celý prostor pod nádrží, dokonce si mechanik lehl pod auto a kontroloval zátěž vozu. Nakonec důkladně prohledali vnitřek vozu, a teprve potom mohl Bachmann naložit věci a odjet. ${ }^{32}$ Tato událost výmluvně svědčí o tom, jak kvalitně tuto tajnou schránku odborníci CIA ${ }^{33}$ připravili a instalovali.

Po tomto incidentu panovaly mezi všemi zainteresovanými obavy, zda není něco na voze v nepořádku, zda při úpravách nedošlo ke změně technických parametrů vozu nebo nevznikla jakási anomálie, která upozorňuje na něco neobvyklého. Jasno do těchto po-

30 Dopis Viléma Prečana Jiřímu Pelikánovi, 7. 1. 1984.

31 Wolfgang Scheur (15. 4. 1921 - 10. 1. 2007) byl německý diplomat, který v letech 1981-1986 působil jako kulturní referent na západoněmeckém velvyslanectví v Praze. Od počátku svého působení se stýkal s nezávislými autory a v roce 1983 se zapojil do dopravního kanálu mezi Jiřinou Šiklovou a Vilémem Prečanem. Toto období intenzivní spolupráce V. Prečan nazval „léta velkého zázraku“. V roce 1998 prezident Václav Havel udělil Wolfgangu Scheurovi Řád T. G. Masaryka II. stupně.

32 Dopis Helmuta Bachmanna Vilému Prečanovi, 8. 4. 1984. Srov. dopis Viléma Prečana Jiřímu Pelikánovi, 21. 4. 1984.

33 Za finanční podpory CIA, tedy americké vlády, se ze Západu na Východ pašovala literatura. CIA podporovala jak vydávání exilových knih a periodik, tak samotný provoz kurýrních cest, jak uvedl A. Ross Johnson, bývalý ředitel Rádia Svobodná Evropa a odborník na studenou válku pro vysílání ČT 24, 26. 1. 2015, https://ct24. ceskatelevize.cz/svet/1496740-nejlepsi-knihovnik-vychodniho-bloku-americka-cia. Srov. Alfred A. REISCH, Horké knihy ve studené válce. Program tajné distribuce knih ze Západu za železnou oponu financovaný CIA, Praha, 2018, 444 s. 


$$
\begin{aligned}
& 4 \times 6=24 \text { Sove } 14 \\
& 41 \times 4=4 \text { frod } 78 \\
& 1 \times 5=5 \text { Lef } 3186 \text { Cfen } \\
& 5 \times 12=60 \operatorname{Liff} 4186 \\
& 6 \times 10=60 \operatorname{lith} 4 / 86 \text { mi } \\
& \text { }
\end{aligned}
$$

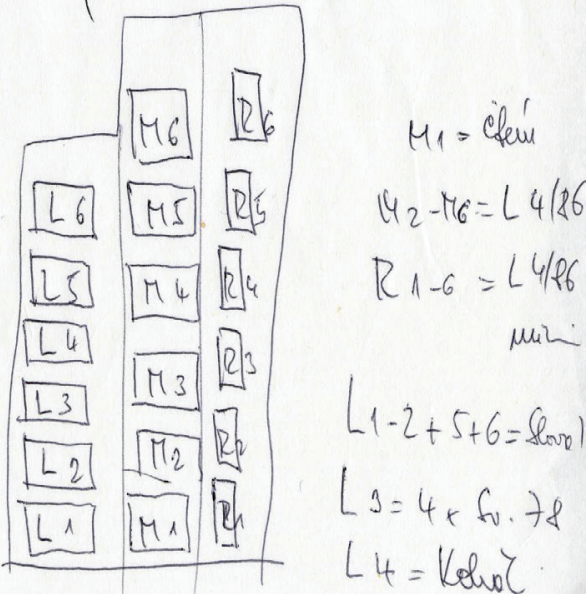

Obrázek 8 - Plánek, podle kterého se plnila tajná schránka v zavazadlovém prostoru, $A N M-\check{C} S D S$.

chybností vnesl dopis Jiřího Stárka Jiřímu Pelikánovi, v němž danou situaci vysvětluje: „V únoru 1984 byla komise na jednom pohraničním prechodu, a právě v tu chvíli, když tam prováděla kontrolu, tak se v autě z Rakouska našlo tisíc digitálních hodinek. Komise hned zjistila, že se to podařilo jen čirou náhodou, a dala zprávu do Prahy, že prohlídky jsou prováděny nedostatečně. Proto byl měsic březen 1984 prohlášen za měsíc plného nasazení a procvičování hlavně mladých finančních strážcü, a tak po celý měsic březen většinu aut zcela rozmontovali a dělali neuvěritelné věci... ".34

Od této nepř́ijemné události jezdil Bachmann do Prahy již sám: „, Auto vypadalo luxusně, sám bych si takové nemohl dovolit. Ale bylo to dobré pro prezentaci na hranicích, a vždycky

34 Archivio Storico della Camera dei Deputati, Řím, fond Jiří Pelikán, kart. 16, dopis Jiřího Stárka Jiř́ímu Pelikánovi z 11. dubna 1984. 
jsem měl na sobě koženou bundu a vypadal jsem cool. Myslím, že ti lidé na hranicích si mysleli, že jedu do Prahy za holkami. "35

V červnu 1984 proběhla poslední cesta $\mathrm{v}$ tomto roce do Prahy. Na podzim zažil Helmut Bachmann s tímto autem neprŕijemnou nehodu. Při soukromé návštěvě přátel zaparkoval vůz ve velmi př́krém kopci „, $K d y z ̌$ jsem auto opouštěl, bylo zaparkované, když jsem se vrátil, tak tam nebylo. Našel jsem ho o 20 metru niže, zadní částí nabourané

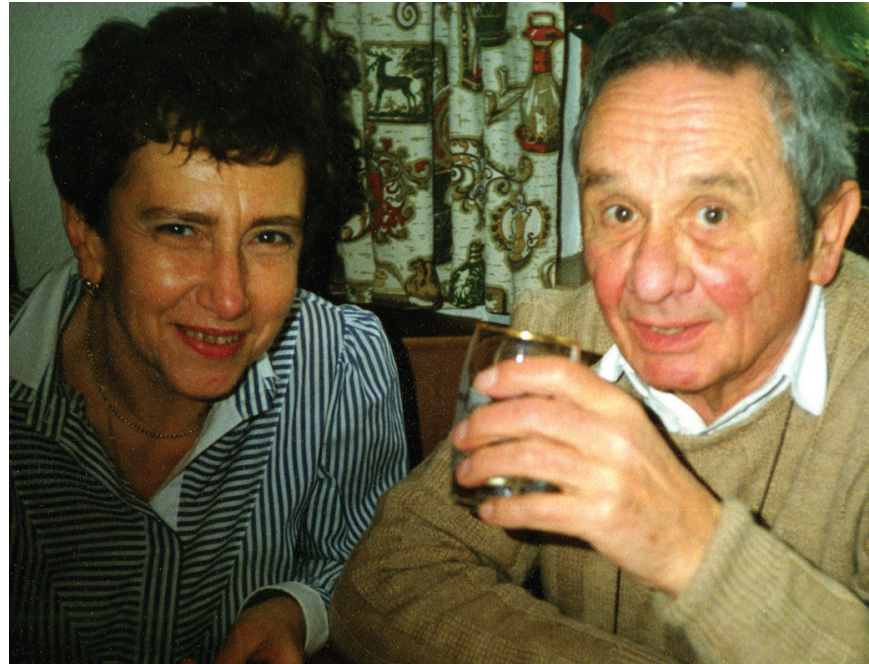

Obrázek 9 - Převzetí zásilek v Praze organizovala J. Šiklová, zde se svým ,dopravcem “ W. Scheurem při setkání u V. Prečana na Schwarzenbergu v prosinci 1989, ANM - ČSDS.

v zahradni zdi. Měli jsme štěstí, že nikdo nebyl zraněn... "36 Kromě poškozené karoserie se zasekl mechanismus tajného dna, ale stále ještě fungoval. Vůz proto musel být opraven, ale pouze důvěryhodným odborníkem, aby automechanik v servisu náhodou nepřišel na vstup do dvojité podlahy. Po poradě s Vilémem Prečanem převezl v listopadu vůz do Frankfurtu. Vozidlo nechal odstavené v garáži na letišti a parkovací lístek, plnou moc, klíče a papíry poslal Vilému Prečanovi do Hannoveru. Ten zajistil vše ostatní. ${ }^{37}$ Podstatné vnitřní škody byly opraveny, ale některé následky havárie byly ještě patrné na karoserii, ty se Bachmannovi podařilo opravit s pomocí souseda ve své rodné vsi v Tyrolsku. ${ }^{38}$

V roce 1985 se cesty „Slovníku“ do Prahy pozastavily. Podle Prečanova vyjádření Jiřímu Pelikánovi se díky vzdálenosti tento podnik prodražoval a stál neúnosně moc času. ${ }^{39}$ Navíc Jiřina Šiklová, která měla tento kanál v Praze na starosti, byla plně vytížena mnohem efektivnější cestou prostřednictvím Wolfganga Scheura. Vilém Prečan i Jiří Pelikán ${ }^{40}$ se snažili najít další uplatnění „Slovníku“, hledat nová spojení v Praze. Nějakou dobu fungovalo auto v režii Jiř́iho Stárka, kterému pomáhala jeho dcera Jana. Helmut Bachmann ve spolupráci s Jiřím Stárkem uskutečnil tři cesty, v prosinci 1985 a následně v lednu a únoru 1986. Jana Stárková vzpomíná, jak náročné bylo dostat věci do prostoru dvojitého dna: , ,... a to nepř́jemné bylo, že když jsem to odklopila (...) tak to bylo hezky udělané, ale ostré. To znamená,

35 Rozhovor autorky s Helmutem Bachmannem, Vídeň 17. 5. 2017.

36 Rozhovor autorky s Helmutem Bachmannem, Vídeň 17. 5. 2017.

37 Korespondence mezi Vilémem Prečanem a Helmutem Bachmannem, 13. 11. a 25. 11. 1984.

38 Rozhovor autorky s Helmutem Bachmannem, Vídeň 17. 5. 2017.

39 Dopis Viléma Prečana Jiřímu Pelikánovi, 5. 5. 1985.

40 Jiří Pelikán pomáhal postupně budovat řadu pašovacích a informačních kanálů. V roce 1984 vytvořil svůj komunikační kanál mezi Vídní a Prahou. Pomocí upraveného osobního auta pašoval německý občan Ulrich Verspohl především texty pro časopis Listy, do Československa vozil dopisy, vzkazy a několik prvních exemplářů Listi̊, in: Jiří VANČURA, Vídeňský kurýr, Listy 1991, roč. 21, č. 2, str. 39-40. 


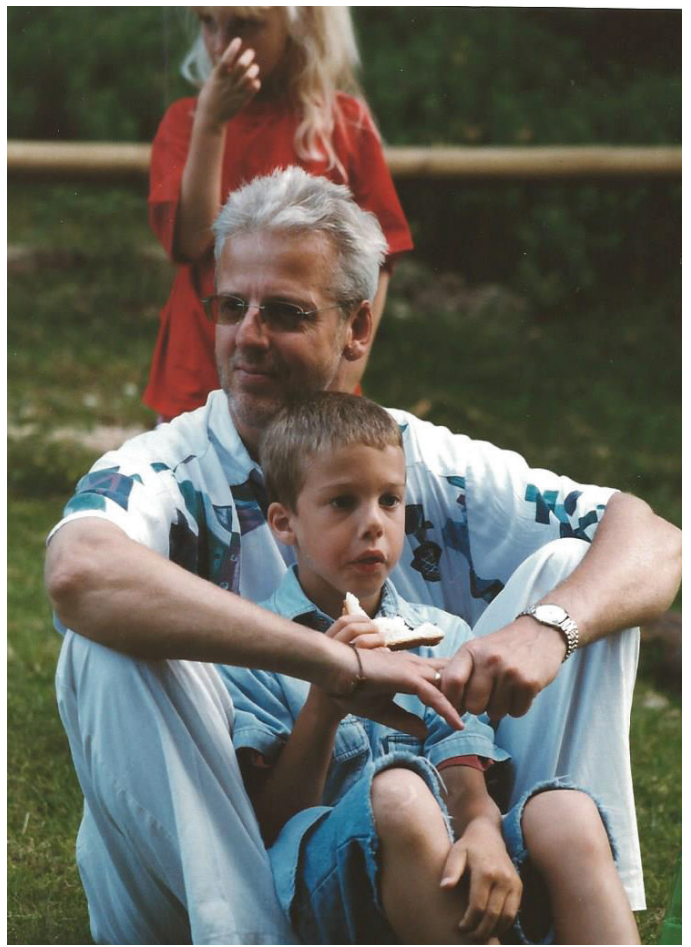

Obrázek 10 - Helmut Bachmann s dětmi, devadesátá léta, soukromá sbirka.

že většina z nás si o to odřela ruce, ale vtip byl v tom, že vše, co se do toho otvoru dávalo, se muselo zabalit do nějakého plastiku nebo néčeho, aby se neodřel ten materiál a aby se to tam dalo pořádně vsunout a ovšem vyndat ven, takže baličky byly většinou podle velikosti Listů, at' už to byl ten velký exemplár̆, nebo ty prtavé, ale složené do velikosti A4... "41

Vilém Prečan stále hledal vhodnou osobu, která by se ujala organizace tohoto kanálu v Praze. Při pracovním výjezdu na Západ navštěvoval V. Prečana Josef Opatrný ${ }^{42}$, s nímž se na této spolupráci později dohodl. Josef Opatrný se v listopadu 1985 ve Vídni také seznámil s Helmutem Bachmannem. Na 31. května 1986 byla domluvena další jízda do Prahy, opět v režii Viléma Prečana. Tentokrát již V. Prečan nepřijel osobně předat „kontraband“, ale poslal jej prostrednictvím Ivana Medka ${ }^{43} \mathrm{v}$ očíslovaných balíčcích a s přesným náčrtkem, jak postupně naplnit skrýšs, ${ }^{44}$ a také s podrobnými instrukcemi k setkání v Praze. Tentokrát se Bachmann setkal se dvěma osobami. Dopoledne v 10 hodin s Josefem Opatrným, na místě, kde se již setkali, a odpoledne v 18 hodin s Jiřinou Šiklovou. ${ }^{45} \mathrm{~V}$ dopisu Bachmannovi Vilém Prečan přesně popsal rituál setkání, jak ho Jiřina Šiklová praktikovala s neznámými kurýry: „Hlavni část bude setkání s jednou dámou, osloví tě česky. Ty odpovišs německy, že nejsi z Prahy, ale z Hannoveru. Ona se zeptá, jestli tam znáš jejího př́tele, a ty odpoviś: pana von Bothmera? (...) Když se nesetkáte přesně v 18.00, čeká se jen 5 minut. To platí pro obě strany. Potom se odejde a vrátí v 18.10 a čeká se opět pouze 5 minut. Opět se zmizí a vrátí se

41 Rozhovor autorky s Janou Stárkovou, Vídeň 16. 5. 2017.

42 Josefu Opatrnému říkali Furiosus, tj. zkráceně FUR - touto zkratkou označoval Vilém Prečan balíčky, které byly určeny pro něho. Josef Opatrný podepsal na konci osmdesátých let spolupráci se Státní bezpečností.

43 Ivan Medek (13. 7. 1952 - 6. 1. 2010) byl významný hudební publicista, disident, exilový novinár̆ a po roce 1989 kancléř prezidenta Václava Havla. Podílel se na reformách pražského jara 1968. Patřil mezi první signatáře Charty 77 a v roce 1978 byl mezi zakládajícími členy Výboru na obranu nespravedlivě stíhaných. V srpnu 1978 odešel do vídeňského exilu, kde se stal spolupracovníkem Hlasu Ameriky a Rádia Svobodná Evropa. Jeho Tisková služba poskytovala informace a dokumenty o situaci v Československu západním tiskovým agenturám, rozhlasovým stanicím a exilovým institucím. Byl blízkým spolupracovníkem Anastáze Opaska, Pavla Tigrida a Viléma Prečana. Patřil mezi zakladatele Československého dokumentačního střediska nezávislé literatury. Do Prahy se vrátil 31. 12. 1989.

44 Ivan Medek ještě několikrát předával H. Bachmannovi balíčky od V. Prečana určené k pašování do Prahy. Několik zásilek a peníze předával také vídeňský přítel Viléma Prečana, profesor Anton Staudinger.

45 Toto bylo první setkání Helmuta Bachmanna a Jiřiny Šiklové. 
v 18.25. Opět se čeká pouze 5 minut. Když se setkáni neuskutečni večer, nový pokus je druhý den brzy ráno v 8.00 na stejném mistě a za stejných pravidel ( $t j$. ještě jednou v 8.10 a 8.25). Potom je po všem a na programu je nouzové řě̌ení. "46

Nouzové řešení znamenalo volat $\mathrm{z}$ telefonní budky Vilému Prečanovi nebo dojít na předem danou adresu. Přri následné cestě $\mathrm{v}$ srpnu byla pro nouzové řešení uvedena

adresa Věry Břachové. Jinak se v korespondenci jména neuváděla, pokud to bylo nutné, Vilém Prečan je sdělil telefonicky.

Helmut Bachmann pašoval knihy a periodika pouze směrem do Československa, ven nikdy nic nevezl. Výjimkou byly jen dvě cesty: v květnu a srpnu 1986, kdy po setkání s Jiřinou Šiklovou souhlasil s převozem materiálů pro Viléma Prečana. To bylo v době, kdy skončila plodná éra Wolfganga Scheura, ${ }^{47}$ který 15 . dubna 1986 dovršil šedesáti pěti let a musel odejít do důchodu, a ještě se za něj nenalezla adekvátní náhrada.

V listopadu 1987 uskutečnil Helmut Bachmann svou poslední cestu do Prahy. Jeho stávající přítelkyně otěhotněla a on již nechtěl dále riskovat. Navíc by technický stav auta vyžadoval větší opravy. ${ }^{48}$ Po dohodě s Jiřím Pelikánem si auto převzal Vilém Prečan a odvezl do Scheinfeldu, kde od podzimu 1986 sídlilo Československé dokumentační středisko nezávislé literatury. Tím skončila úspěšná éra „Slovníku“, tzv. rakouské cesty.

V té době už nebyl takový tlak na přepravu, která nebyla velká objemem. Od záŕí 1986 začala neméně efektivní spolupráce s kanadským diplomatem Peterem Bakewellem, ${ }^{49} \mathrm{kte}-$ rý nahradil Wolfganga Scheura. Spojení na kanadské diplomaty pomohla zprostředkovat

46 Dopis Viléma Prečana Helmutu Bachmannovi, 8. 5. 1986.

47 Za zásluhy o českou a slovenskou nezávislou literaturu obdržel v roce 1986 Wolfgang Scheur od českých nezávislých autorů Rád české knihy (Ordo libri bohemici).

48 Rozhovor autorky s Helmutem Bachmannem, Vídeň 17. 5. 2017. Srov. dopis H. Bachmanna Vilému Prečanovi 27. 8. 1987.

49 Peter Bakewell (2. 10. 1949 - 5. 10. 2012) byl kanadský diplomat, který působil v Praze v letech 1986-1988 na kanadském velvyslanectví jako druhý tajemník a vicekonzul. Současně působil jako kurýr mezi čs. opozicí a exilem. V diplomatickém voze převezl přes hranice do Prahy tři tuny exilových knih, korespondence, ale také kopírku nebo klávesy pro undergroundovou skupinu The Plastic People of the Universe. Český ministr zahraničních věcí Karel Schwarzenberga mu udělil v roce 2007 cenu Gratias agit za jeho pomoc při udržování spojení mezi českými disidenty a jejich přáteli na Západě. Státní bezpečnost na něj vedla spis s krycím názvem „Lumír - 86“. 


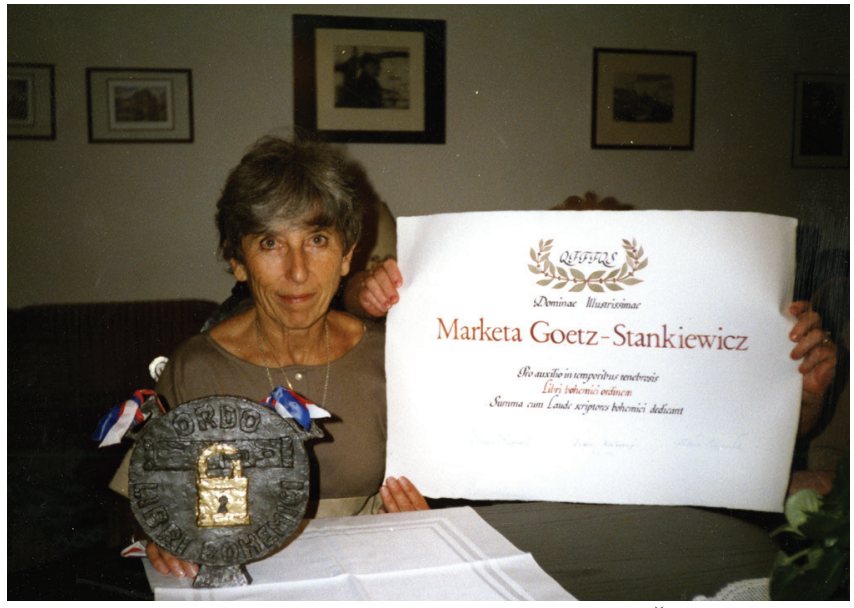

Obrázek 12 - Markéta Goetzová-Stankiewiczová s Řádem české knihy (Ordo libri bohemici), který od roku 1986 udělovali čeští autoři svým obětavým zahraničním spolupracovníkům za zásluhy o nezávislou literaturu, ANM - ČSDS.
Markéta Goetzová-Stankiewiczová, ${ }^{50}$ Kanad'anka s českými kořeny. Po dva roky pak Peter Bakewell velmi často jezdil na západoněmeckou stranu hranic, kde na něj čekal Vilém Prečan a kde si vyměňovali knihy, korespondenci, ale i technické zařízení pro vydávání samizdatu. Po jeho odchodu z kanadské ambasády zprostředkoval Wolfgang Scheur setkání Viléma Prečana s velvyslaneckým radou západoněmeckého velvyslanectví Peterem

Metzgerem. ${ }^{51}$ Ten navázal na intenzivní kurýrní činnost svých předchůdců a činil tak až do roku 1989.

Helmut Bachmann byl jedním ze statečných a obětavých zahraničních přátel, kteří pomáhali udržovat spojení mezi domácí opozicí a institucemi svobodného světa. Díky této činnosti se dařilo narušovat informační bariéru mezi Východem a Západem. A pouze takovouto cestou mohl exil poskytovat služby, které domácí disent ke své činnosti nutně potřeboval. Díky komunikační síti kurýrů se dařilo zprostředkovávat necenzurované informace o aktivitách nezávislých občanských iniciativ a o porušování lidských práv v zemi. Tím bylo možné získávat mezinárodní podporu a humanitární pomoc obětem politické perzekuce, a tak se často neznámí bezejmenní kurýřri přičinili o to, aby doba normalizace byla snesitelnější a v konečném důsledku také padla.

50 Markéta Goetzová-Stankiewiczová, profesorka srovnávací literatury na univerzitě ve Vancouveru, autorka a esejistka. V roce 1948 odešla s rodiči z Československa a usadila se v Kanadě. Zde propagovala českou kulturu, zaměřila se na díla vydaná v samizdatu, překládala je a psala o nich. Při svých návštěvách Československa se seznámila se zakázanými autory, např. s Václavem Havlem, Ivanem Klímou, Josefem Topolem, Ludvíkem Vaculíkem, pomáhala také při pašování knih. V roce 1988 jí čeští zakázaní autoři udělili tajný Řád české knihy (Ordo libri bohemici), za zásluhy o nezávislou literaturu.

51 Peter Metzger (11. 3. 1937 - 10. 12. 2017) byl západoněmecký diplomat, který působil v Praze v letech 19861989. Od roku 1987 se plně zapojil do dopravního kanálu Šiklová-Prečan. Peter Metzger byl mj. velvyslancem v Čadu, Jemenu, Bulharsku a Norsku. 